\title{
41919
}

\section{Black women's oppositional gaze making images}

\section{Michelle Sales \& Bruno Muniz}

\begin{abstract}
:
In this article, we consider the audio-visual production carried out by black women in Brazil since the second decade of the 21 st century. Our objective is to propose a reflection, adopting an intersectional approach, on how an oppositional gaze creates images that break with racist stereotypes and challenge whiteness (hooks, 1992). We argue that the production of black women in Brazil questions the reproduction of institutional racism and digs deeper into the issue of colonial past. They create a narrative dispute that the oppositional feminine gaze imposes on the film industry.
\end{abstract}

Keywords: oppositional gaze; intersectionality; cinema; institutional racism.

\section{Resumo:}

Considerando a produção audiovisual realizada por mulheres negras no Brasil depois da segunda década do século $X X$, propomos pensar, através de um viés interseccional, como um olhar opositivo (hooks, 1992) criador de imagens rompe com estereótipos racistas e interpela a branquitude. Argumentamos que a produção de mulheres negras no Brasil, interpela, através da disputa narrativa que o olhar opositivo feminino opera no campo do cinema, a reprodução do racismo institucional e aprofunda a questão do legado colonial.

Palavras-chave: olhar opositivo; interseccionalidade; cinema; racismo institucional. 


\section{Introduction}

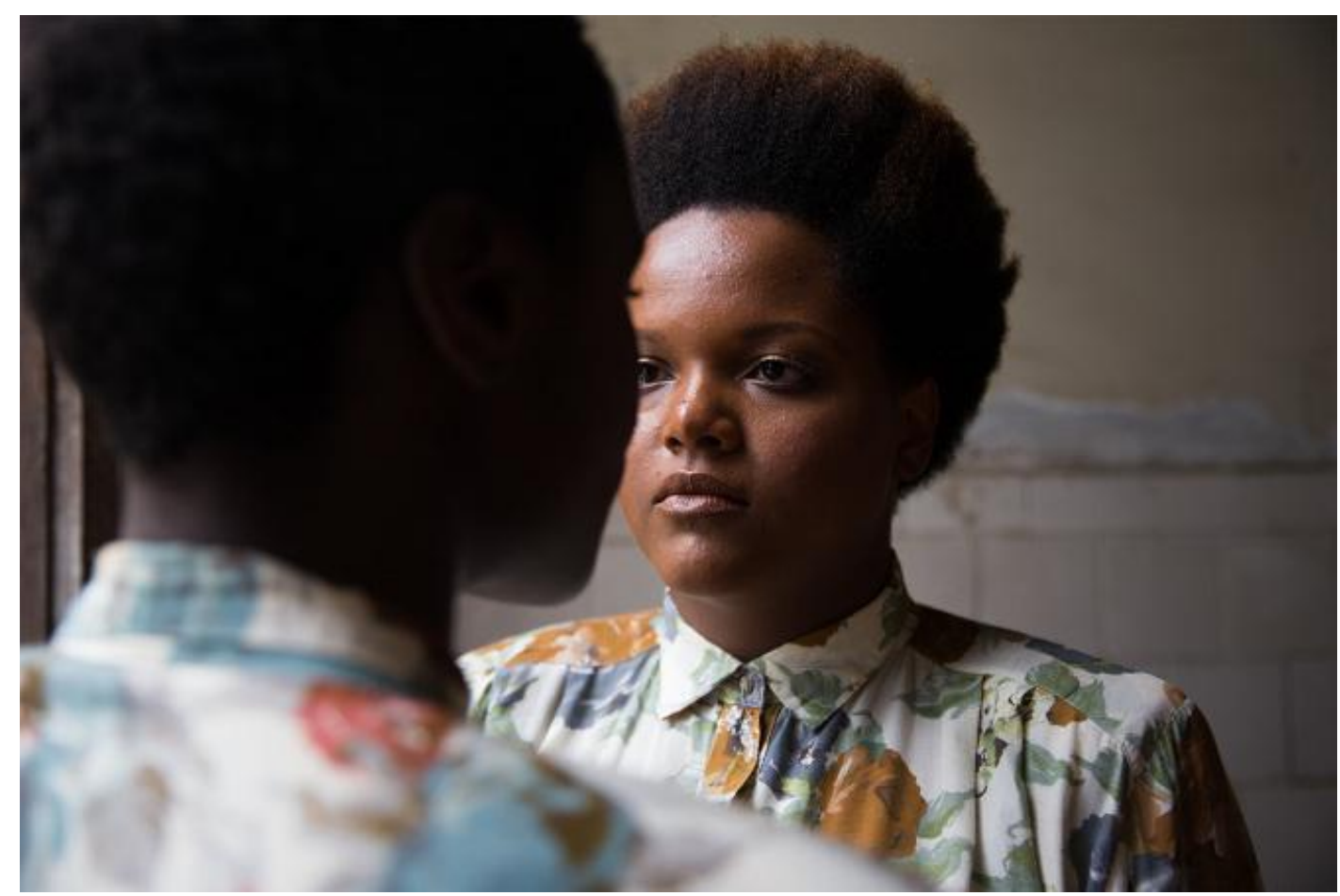

Figura 1: Kbela, Yasmin Thainá, 2015 @yasminthaina. Fonte:

https://www.vice.com/pt_br/article/78zqbq/kbela-quando-o-cabelo-da-mulher-negra-vira-filme

In audiovisual productions that depict racialized populations, the white gaze over black bodies usually reinforces racist stereotypes. As to the work of female filmmakers, racial inequality is equally striking. More than reinforcing racial stereotypes, the film industry is both a product of institutional racism, which permeates our society, and a vehicle to its dissemination. As pointed out by the research project $A$ cara do cinema nacional: gênero e cor dos atores, diretores e roteiristas dos filmes brasileiros (2002-2012), developed by the Affirmative Action Multidisciplinary Studies Group (GEMAA, 2014) from IESP/UERJ, most Brazilian movie directors are male and white, which reflects a white gaze predominance in the film industry. According to the same study, the presence of black women as directors of Brazilian feature films is non-existent in the period under analysis (2002-2012). We would like to update these statistics, as the movie Café com Canela, released in 2017, was directed by Ary Rosa and Glenda Nicácio. The filmmaker Glenda Nicácio is the founder of Rosza Filmes, in the Recôncavo Baiano, and a graduate of the film course that was recently created by the Federal University of Recôncavo da Bahia in the emblematic city of Cachoeira, where an important Brazilian film festival is transforming the national cultural scene. 
In the audiovisual production of feature films by white female filmmakers in Brazil there is a continuity of stereotypes, as pointed out in the text Pós-colonialismo(s) e o cinema brasileiro (Sales, 2018), where the repercussion of the film Vazante (2017), by Daniela Thomas, is brought under analysis. The same way movies have exercised power over black lives and roles, we herein propose to reflect, adopting an intersectional perspective, about the idea of an oppositional black gaze (hooks, 1992) which creates images and is capable of breaking with stereotypes, questioning and making a critique of coloniality, through the analysis of the cinematographic production of black women in Brazil.

The term coloniality used here expresses the permanence of colonial, racial and patriarchal structures after colonialism was formally brought to an end (Quijano, 1998). In the meantime, as these structures were updated, following the political independence processes in Iberian America, they are not identical to those observed during the formal colonialist period, but they still show how the exercise of power in our days is closely linked to a colonial past.

Thus, as Jaime Amparo puts it in his book The Anti-Black City: Police Terror and Black Urban Life in Brazil, this paper is born from a general desire to address the genesis of an antiblack world. That is, we agree with Jaime Amparo when he speaks of a world regulated by an "anthropophagic economy of flesh" (2018: 17), in this case the black flesh. The concept of institutional racism is a decolonial concept that assumes a continuity between colonial practices and the practices of our so-called liberal democracies (Hesse, 2004).

In the field of sociology, it has become clear that many studies that try to understand whiteness eventually refocus it, creating a mechanism through which white people deal with the guilt of benefiting from racial and colonial structures. The very notion of white fragility shows how white people deal with their affections and rapidly assume a vulnerable stance when challenged about racism (DiAngelo, 2011). However, whiteness as presented by black women through an oppositional gaze is usually far from fragile, but rather invasive and violent, as we show in a number of films.

On the other hand, literary, musical and cinematographic production by white people is thought as having intrinsic aesthetic value. In other words, it is assumed that knowing and mastering repertoires of high cultural capital enables individuals or groups to position themselves in a more advantageous way than those who do not. This is possible as the intrinsic aesthetic value of these repertoires was socially constructed and assigned (in general) to white people through the perpetuation of Eurocentric aesthetic paradigms, born of a colonial legacy with implications in the fields of culture and art. 
Thus, in this text, we try to remove whiteness from a position of "normality", bringing the artistic production of black women to the center and highlighting not a white world made fragile and cynical by structural racism, but a world marked by the coloniality of antiblack, sexist and homophobic power. This displacement is key to prevent studies on whiteness from promoting a refocusing of whiteness (hooks, 2013). It is our main goal to think of an oppositional gaze that creates images outside the space of the spectator and in command of the narrative, one that is capable of assuming control over representation itself. According to bell hooks, in her compilation Black Looks: Race and Representation (1992), the first time black Americans sat down to watch TV, they became aware that what they saw was connected to the ideals of white supremacy. That is, looking at such images and relating to white American cinema was an exercise on critical thinking in itself, capable of questioning the negation of black representation and the reinforcement of stereotypes. The notion of an oppositional gaze is therefore linked to the creation of critical spectatorship, since "black looks, as they were constituted in the context of social movements for racial uplift, were interrogating gazes." (hooks, 1992: 116). Still according to the author,

Spaces of agency exist for black people, wherein we can both interrogate the gaze of the Other but also look back, and at one another, naming what we see. The "gaze" has been and is a site of resistance for colonized black people globally. Subordinates in relations of power learn experientially that there is a critical gaze, one that "looks" to document, one that is oppositional. In resistance struggle, the power of the dominated to assert agency by claiming and cultivating "awareness" politicizes "looking" relations - one learns to look a certain way in order to resist (hooks, 1992: 116).

American independent black cinema would emerge from this oppositional point of view, from the creation of a critical spectatorship capable of questioning image, representation and racism. Thus, in assuming the concept of an oppositional gaze as a formative paradigm not only for North American black cinema, but for the many waves of black cinema around the world, we propose to reflect about the way in which black women have produced cinema in Brazil, upholding, in many ways, an oppositional gaze towards whiteness, racism and sexism, while pointing out the continuity of colonial dynamics. Our second challenge involves carrying out an intersectional analysis that does not promote the equivalence of different types of oppression nor a cumulative perspective, where elements such as race, class, sexual orientation and gender are seen as independent forces that add up. An intersectional analysis should not forego the racial variable, since it is precisely in this context that the concept is developed. At the same time, thinking about different forms of oppression independently goes against historical experience, as 
they involve a continuity of relations impacted by the coloniality of patriarchal and racist power. We have thus chosen to analyse the most recent (last ten years) audio-visual production by black women in Brazil, highlighting the way in which whiteness is challenged through the oppositional gaze of these filmmakers.

\section{Cinema and racial representation in Brazil}

Although the representation of black men and women (as well as native peoples) in Brazilian culture is not a new issue, it was only in the mid-1970s that a small group of black artists connected with the Brazilian cinema started questioning the stereotypes to which the black/African population was subdued to, as well as the social role occupied by black individuals in the audio-visual industry. As stated by Noel dos Santos Carvalho and Petrônio Domingues:

In the 1970s, the black movements articulated a broad agenda of struggles, ranging from general political claims against racism to demands of a symbolic order, which included the construction of positive models of self-representation. Theater, literature and cinema were all galvanized around this identity affirmation project. Zózimo Bulbul, one of the main Afro-Brazilian directors at the time, connected his work to the aspirations and expectations of the black movement. He directed the short films Alma no olho (1973), Artesanato do samba (1974), with Vera de Figueiredo, and Dia de alforria (1981), and the feature Abolição (1988). Other black filmmakers also entered the scene. Waldir Onofre directed As aventuras amorosas de um padeiro (1975), Antonio Pitanga, Na boca do mundo (1978), and Quim Negro, Um crioulo brasileiro (1979) (Carvalho \& Domingues 2018: 11).

Viewed as a forerunner of black Brazilian cinema, Zózimo Bulbul left a great legacy not only as a director, but also as an actor and cultural producer. In 2007 he founded the important Afro Carioca Cinema Center in Rio de Janeiro, a reference in recent debates on racism. Zózimo made his film debut alongside the actor (and intellectual) Abdias do Nascimento in the short film by Leon Hirzsman Pedreira de São Diogo included in the movie Cinco Vezes Favela (1962). As an actor, he was cast in a number of emblematic Brazilian movies, such as Ganga Zumba (1967), by Cacá Diegues and Terra em Transe (1968), by Glauber Rocha. Concerning his relationship with Abdias Nascimento, Joel Zito Araújo (2016) points out that:

We can see a continuity between the cinematographic work, the artistic and militant action of Zózimo Bulbul and the heritage left by the late Senator Abdias do Nascimento, creator of the Teatro Experimental Negro (TEN) in the 1940s. The two pursued the goal of denouncing the false myth of racial democracy, fighting discrimination against blacks and promoting black self-esteem. This is what we see in the dramaturgic and plastic works of Abdias Nascimento and in the movies of Zózimo Bulbul. 
Although the issue surrounding the representation /self-representation of the blackness was strengthened in the Brazilian cinema of the 1970s (as this was a central theme in the literary and theatrical output of the time), Noel dos Santos Carvalho and Petrônio Rodrigues argue, in their paper Feijoada Dogma: The invention of the Brazilian black movies, that, in political, aesthetic and even formal terms, black cinema in Brazil comes into existence (and appear in the media) in the early 2000s only. As a landmark for this event, they point to the celebration of the exhibition Feijoada Dogma, organized by the filmmaker Jeferson De, in which the manifesto Gênese do Cinema Negro Brasileiro would be read and discussed:

On August 17, 2000, the Folha de S. Paulo newspaper reported that Feijoada Dogma promised to be one of the attractions of the 11th São Paulo International Short Film Festival by proposing a debate on the image of blacks in Brazilian cinema, a new theme in the program of the event, which had already shown, in 1997, in the Focus section, works by black filmmakers from several countries. Thus, the Genesis of Brazilian Black Cinema, Manifesto, written by the young filmmaker Jeferson De (artistic name of Jeferson Rodrigues de Rezende), then a film student at the University of São Paulo (USP), was read and debated in one of the festival sessions. Six films (among short films and documentaries) were part of the Dogma Feijoada - Mostra da Diversidade Negra program: Dia de alforria (Zózimo Bulbul, 1981), Abá (Raquel Gerber and Cristina Amaral, 1992), Almoço executivo (Marina Person and Jorge Espírito Santo, 1996), Ordinária (Billy Castilho, 1997), O catedrático do samba (Noel Carvalho and Alessandro Gamo, 1999) and Gênesis 22 (Jeferson De, 1999) (Folha de S. Paulo, 2000a) (Carvalho \& Domingues, 2018: 1).

The Feijoada Dogma exhibition was a Tropicalist attempt to paraphrase the principles of Dogma 95, a Scandinavian filmmaking manifesto that launched important names in world cinema, such as Lars von Trier. Just as the European equivalent, Feijoada Dogma intended to break with visual stereotypes, but also with filmmaking norms. In Gênese do Cinema Negro Brasileiro, Jeferson De argues that black cinema, in order to exist:

(1) must be directed by a black Brazilian director; (2) the lead actor must be black; (3) the theme of the movie must be related to black Brazilian culture; (4) the movie must have a suitable schedule. Urgent-movies; (5) black (and other) stereotyped characters are forbidden; (6) the script must privilege the average black Brazilian; (7) superheroes or criminals must be avoided (Carvalho \& Domingues, 2018: 4).

During this period, few black women managed to maintain a regular presence in Brazilian cinema, and although it is possible to highlight the relevance of many actresses, the debate surrounding the role occupied by black women and the actual occupation of the narrative post as a female director, whether in cinema or television, is recent. Even the Feijoada Dogma movement did not propose an agenda which included black women, as 
pointed out by researcher Edileuza Penha de Souza in her recent article Mulheres negras na construção de um cinema negro no feminino:

(...) although the Feijoada Dogma Movement made it possible to discuss the chance of a Brazilian cinema made by blacks, creating a small agenda for thinking about black cinema, the text makes no reference to the role of black women in cinema (Souza, 2020: 178).

Both of the articles mentioned call to attention another important document for the consolidation and debate surrounding a Brazilian black cinema, the Recife Manifesto, articulated by black actors, actresses and directors, who were present at the 5th Recife Film Festival. In this manifesto "of a prescriptive and more politicized nature", according to Edileuza da Penha (2020), the political and identity issue of blacks in Brazilian society was better presented and articulated, and offered an opening to include the issue of black women in cinema. In the aforementioned paper Feijoada Dogma: The invention of the Brazilian black movies, the authors argue that:

In short, the Recife Manifesto demanded the inclusion of black people in the entire audiovisual chain. In order to make such a project effective, it demanded legal sanctions from television stations, film producers and advertising agencies - which insisted on the practice of racial discrimination - and evoked a "broad, general and unrestricted alliance" amongst all audiovisual producers of all ethnicities in order to create a "new aesthetics" for Brazil, with a view to promoting its "multiraciality" (Carvalho \& Domingues, 2018: 7).

\section{Intersectionality and cinema}

The expansion of colonialism as a form of economic, political and social power has carried with it a complex linguistic/discursive apparatus capable of corroborating the European omnipotence and superiority, whose developments in the field of culture and the formation of identities worldwide are devastating. As Ella Shohat and Robert Stam argue, "colonialist culture constructed a sense of ontological European superiority to 'lesser breeds without the law'” (2006: 45). In Critique of Black Reason, Achille Mbembe (2017) maintains that the territorial conquest, economic domination and political submission of colonized peoples across all continents has dragged along a complex of European fantasies, whose uncountable effects still coincide with the work of death and precarization, along with the impoverishment and subordination of many lives within the political sphere, but also in the field of symbolic production. This delirium of superiority, alongside the civilizing fiction that impregnates the colonisation discourse, a pillar of modernity, can be called eurocentrism. Eurocentrism therefore represents the establishment of white and European standards as the paradigm from which knowledge is created (Araújo \& Maeso, 2016). The westernization of the world was carried out by 
the project of colonialism under the flag of "civilizing barbaric peoples", one of the central discourses that legitimize the barbarity carried out by the Europeans in different regions of the world, including evangelical missions that resulted in the death of thousands of native communities. By universalism, we understand all narratives that are (generally) produced by white people about humanity, in a way that is levelling and capable of suppressing differences, favoring an "equality among human beings". Eurocentrism, as a colonizing discursive force, imposes itself as a norm, submitting peoples and cultures to new paradigms and ways of thinking, living and feeling. The concept of intersectionality that we intend to develop, in order to think about the creation of an antiracist oppositional view of the white/Eurocentric world, has the potential to expose what is concealed by universalism/eurocentrism. However, the appropriation of the intersectionality concept in the most diverse contexts of thought can render the racial question invisible or push it into the background. This was not the goal of Kimberlé Crenshaw when she coined the term, used, for instance, to analyse the case "Hill versus Thomas" in her essay Whose story is it, anyway? Feminist and antiracist appropiations of Anitta Hill (Crenshaw, 1992).

In 1991, Anitta Hill, a black prosecutor, saw one of her interviews with the FBI leaked to the press and was summoned to testify. She then proceeded to accuse Clarence Thomas, a United States Supreme Court candidate appointed by George W. Bush, of sexual harassment. Crenshaw discussed how the "Hill v. Thomas" trial was characterized by two distinct narratives: the lynching narrative, built with black men at its core, and the rape narrative, where white women occupied the centre. Gradually, the fact that Anitta Hill was a black woman at the centre of an accusation was rendered invisible, promoting instead not only a lynching narrative, but mostly an appropriation of the debate by white women. Crenshaw concluded that black women have a limited chance of defending themselves, explaining and exposing institutional racism from a perspective that takes into account racial, gender and class structures. The appropriation of intersectionality by white feminism and the continuous denial of racism are issues that black feminism has raised, and they must also be exposed in the moviemaking industry. One could argue that in the case of "Hill versus Thomas", the issue in hand is not denialism or the promotion of white supremacy, since both parties were black individuals. However, if we fail to understand this case from the perspective of institutional racism, we may erroneously think that Crenshaw is defending a higher degree of determination in gender relations. The author is constantly discussing institutional configurations and racism within institutions, e.g. the legal field. However, strategies to incorporate gender into social analysis do not always consider the necessary connection between intersectionality and institutional racism, even when intersectionality is mentioned. 
Gender mainstreaming is, according to the European Commission (2004), a set of policies that promote equality between men and women. These are currently being expanded to include other forms of inequality, as the EU is revising its policies to "address multiple inequalities" (Squires, 2007: 47). The term intersectionality is increasingly used, running the risk of becoming a form of "gender mainstreaming" only (Yuval-Davis, 2006: 204).

Intersectionality should shed light over the oppression endured by black women, instead of putting gender at the centre. Gender oppression should not gain visibility at the expense of racism. It is worth noting that she uses the phrase "feminism must be recast in order to reach women who do not see gender as relevant" (Crenshaw, 1992: 435). Therefore, the original concept of intersectionality was not about the expansion of feminism, but about its reformulation.

In considering the "Hill v. Thomas" case from the institutional perspective, it becomes clear that what is mainly at stake is not the conflict between a black woman and a black man, but between a black woman and a racist and sexist institutionalism. Strategies for the integration of diversity or race will have a limited impact if they are not followed by a critique of institutional racism, as feminist policies are equally pervaded by this. The way Squires (2007) explains the difficulties underlying the diversity integration proposal clearly shows the limits of white feminism where the antiracist struggle is concerned:

For instance, many feminists have expressed concern that the recognition of ethnic minority and religious group rights may limit and erode the pursuit of gender equality (Okin 2000, Skjeie 2006), leading to anxieties that a multiple equalities agenda may undermine rather than facilitate gender justice. The extension of mainstreaming processes to fields other than gender has therefore been perceived by some feminists as a worrying development, signalling a diminution of concern with gender and a marginalization of feminist concerns in the policy agenda (Squires, 2007: 48).

The appropriation of intersectionality by a white agenda is combined with the denial of institutional racism and other forms of racism and their particularities. Although intersectionality was in fact coined with a certain cumulative logic, Crenshaw is very assertive as to the connection of the term to the reality of black women and institutional racism. However, the European Institute for Gender Equality website defines intersectionality as a:

Analytical tool for studying, understanding and responding to the ways in which sex and gender intersect with other personal characteristics/identities, and how these intersections contribute to unique experiences of discrimination (Mediterranean Institute of Gender Studies, 2009: 1). 
The experience of black and other racialized women is erased while sex and gender are brought to the centre, racism goes unmentioned and, instead, the expression "experiences of discrimination" is used. Racialization processes are described as "personal characteristics/identities". Another example can be found in a request from the Canadian government for the financing of a fund called Women as Agents of Change in the Americas, where expressions such as "intersecting factors of identity" and "discrimination" can be found, but gender is, again, placed at the centre. By browsing the websites of institutions committed to gender equality around the world we find other examples of institutional uses of intersectionality that put gender at the centre while moving racism to the background.

\section{Oppositional gaze}

Alongside the debate surrounding representativeness on movie (and television) screens, a new discussion involving gender, sexuality and race gained momentum at the beginning of the 21 st century. The line of feminist thought that highlighted the levels of oppression to which a black or brown woman is subjected to throughout her life, almost always marginalized in an intrinsically patriarchal, sexist and racist society, such as the Brazilian society, became, in the second decade of the 21st century, an inevitable discussion in Brazil.

Intersectional feminism, a Marxist line of thought that emerged in the United States in the 1970s, had (and still has) amongst its leaders Angela Davis, Patricia Hill Collins, bell hooks, and others, known to the Brazilian academic public, yet still strongly connected to the gender debate. For instance, the huge role that women like Angela Davis played in the criticism of the American prison system and the broad struggle of black American feminism for criminal abolitionism is widely unknown. lack Intersectional feminism rethinks race, gender and social class interrelations. It challenges white feminism, by considering race and class as factors that one must take into consideration to struggle against gender oppression. In Brazil, also from the 1970s onwards, black activists, such as Lélia Gonzalez and Sueli Carneiro, also questioned racism within feminist struggles, a debate that black feminism and the so-called Fourth Wave Feminism and its new protest methods revived during the 21 st century. There is another component that is worthy of mention: the 2000s are characterized by the emergence of important organizations in the favelas, such as CUFA - Central Única de Favelas - and AfroReggae, both located in Rio de Janeiro. In both, the very residents (mostly black men and women) assume leadership. These new institutions galvanized the production of peripheral culture in Brazil, highlighting the relevance of the audio- 
visual work growing in favelas, as well as hip-hop, rap and funk, which are great vehicles for the mass dissemination of peripheral voices.

These black voices form a significant counter-narrative front that has been growing since the 2000s, stimulated by affirmative action policies, such as the establishment of a quota system in public universities and other initiatives in the areas of education and culture. These young voices define a new positive relationship with body, colour and hair amongst black Brazilian women, physical traits that are often appropriated and depicted by the media and cinema in a pejorative and/or subalternized way. The existence of a new social environment in Brazil has allowed for these racialized voices to flourish and emerge in different aspects of the cultural and cinematic production

In the wake of these social transformations, brought about by the Fourth Wave Feminism, a new movement has emerged in the Brazilian context, which has been dubbed as the Black Female Cinema, a term that can be traced back to the Brazilian researcher Edileuza da Penha (2020). According to her:

Our choice to debate a Black Female Cinema is rooted in strategies of belonging and affection. The production of black female directors makes it possible to discover a cinema that breaks with the stereotypes and racism "of a society that is aesthetically dominated by the white paradigm" (Souza, 2020:12).

Also an expert on the subject, researcher Janaína Oliveira (2016) prefers to talk about black cinema in a female perspective and points out the specificity of this audio-visual production by black women in Brazil, where the short film format dominates. According to the renowned work by Joel Zito Araújo, A negação do Brasil: o negro na telenovela brasileira (2001), the black Brazilian woman has always been present as an object of representation either on television or cinema, assuming the role of the black mother, the obedient slave, the mucama (a sexual slave), the samba mulatta, all of which racialized, derrogatory and perjorative roles. The black woman had hardly ever been thought of as an individual, a producer of images and narratives. Still according to Joel Zito Araújo (2019), invited by ABL in 2019 to teach the "Blacks in Brazilian Cinema" colloquium, the Brazilian film industry has one of the lowest percentage of black workers, including actors in relevant roles. The idea of a black cinema emerges alongside the movement known as the New Brazilian Cinema of the 1960s and 1970s, as was already pointed out, but in opposition to it. The intention was to denounce the whitening of Brazilian cultural production, the permanence of black men and women in stereotyped roles, and the pervasive racism in the Brazilian social imaginary, as pointed out in another text:

Black cinema, although it has deeper roots, will expand and deepen its action around the world in the 1970s, driven by a socio-cultural context of 
black affirmation, as was the case in Brazil. Black cinema is broadly defined as a conceptual stance intended to express the difference of a new socio-cultural positioning of the afrodescendant and build an affirmative image of the black people and their culture. Moreover, the pursuit goes beyond mere representativity, that is, the construction of narratives and imaginaries where the black man or woman is the main theme, it is a negotiated pursuit for protagonism - taking the place of those who speak and those who make the films. Contrary to the official national cinematography that was produced within the New Cinema movement in Brazil, black filmmakers, such as Zózimo Bulbull, Luiz Paulino dos Santos and Adélia Sampaio, emerged, denouncing a crisis in the representation of the black people and starting to negotiate new regimes of visibility for black men, black women and afro-descendants in Brazil (Sales, 2019: 325).

Adélia Sampaio is consensually considered to have been the first black Brazilian woman to direct a short and a feature film (Sacramento, 2017). Daughter of a domestic servant, Adélia Sampaio, was born in Belo Horizonte, and moved to Rio de Janeiro when she was only 4 years old, spending long periods of her life in orphanages. She worked as a camera operator at Difilm, where she began organizing a film club and to work in the production of a number of movies as makeup artist, script supervisor, camera woman, producer and film editor. In 1979 she debuted her first short, Denúncia Vazia. In 1984, she became the first black female director behind a feature film, Amor Maldito. The script for this film, as Janaína Oliveira points out, "does not deal with the racial issue, it innovates by bringing to the screens a romantic relationship between two women, from a female perspective" (Oliveira, 2016: 3).

The 1984 movie shows a predominantly white universe, including those who are legally oppressed, and presents the legal sphere from a critical perspective of someone who knows the selectivity of the penal system. In Amor Maldito, Adélia Sampaio uses the repression of homosexuality to portray a white and sexist justice system, a theme that in itself stirred a brand new debate in the Brazilian society. Because of this, the film had to overcome several obstacles to find ways to circulate and be screened, choosing (or being forced to choose) the label of porn cinema to enter the exhibition market:

To make the film circulate was another dilemma, for, according to Sampaio, movie theater owners claimed there would be riots because of the theme involving a romantic relationship between two women. To solve this, a distributor suggested that Amor Maldito should be presented as a porn movie: 'We disguise it as a porn film and it will work', said the distributor, according to Sampaio (Oliveira, 2016: 3).

The pioneering spirit of Adélia Sampaio marks the entry of black women in the Brazilian moviemaking industry, as creators and directors. The generation we will be addressing now seems to have expanded the legacy of Adélia Sampaio and points towards the 
creation of films which deal with the self-representation of black women and the enunciation of a gaze that opposes whiteness. This will be our focus point as we carry out an analysis of the movies produced by black women in the Brazilian and Portuguese contexts.

To understand why Brazilian audio-visual production (mostly from the second decade of the 21 st century) makes room for voices that were, until then, marginalized (as was the case of black women) we need to go back to the affirmative public policies enforced from the 2000s. These were essential tools for historical reparation and social inclusion, but also for the creation of film courses in circuits that did not exist before, such as the Bachelor's Degree in Film created at the Federal University of Recôncavo da Bahia, which gave birth, for instance, to the CachoeiraDoc Film Festival. Looking at the editorial stance of the event, we perceive an innovative curatorial dynamic, created and consolidated over the last decade. One can consider this festival a window opened by cinema against hegemony in its own definition.

As we point out in the paper Cinemas Pós-Coloniais e Decoloniais em Contextos de Crise (Andrade \& Sales, 2020), besides the CachoeiraDoc, other important "windows" were opened over the last decade, encouraged by a certain galvanization of the Brazilian cultural scene:

In recent years, we have witnessed a new cultural moment in Brazil: a critical period, sharpened by transformations in the cultural field and strongly influenced by disputes over the narrative production by minority groups. In this article, we want to point out that contemporary Brazilian cinema further developed some guiding principles, broadening the debate on new engagements with image and new relationship, perception and production modes. It is important to note that, from the second decade of the 2000s onwards, there is a new stage in thought dynamics and in decolonial cultural production (Maldonado-Torres, 2013), which increases tensions towards memory and the colonial past, as well as their sociocultural and aesthetic unfoldings. The International Film Window of Recife, a film festival with eleven editions to date, is born of this context, encompassing new voices and featuring movies that propose a deeper reflection on the Brazilian political situation and its relationship with culture, as well as identity issues, based on themes such as race and gender (Andrade \& Sales, 2020:213).

Someone who watches Amor Maldito looking for references to blackness will leave, to say the least, frustrated, as the racial issue is always addressed in a brief and simple manner, and never explicitly pinpointed. The only black witness speaks of "persecuted minorities" and makes a critical, yeat short, speech about the persecution of the lead actress, a white woman who stands accused of murder, for being a lesbian. This testimony is cut short and the witness quickly returns to the public. 
The concept of intersectionality is linked, as it is formulated, to its initial purpose: criticize dominant narratives that do not take black women into account. In this sense, Adélia Sampaio reveals by hiding. The director chooses to make a film based on a story where black reality is barely brought to the debate, yet speaks volumes about whiteness and anti-black patriarchy, exposing a structure that is deeply rooted in the colonial period: the justice system.

The backstage of the trial reveals the cynicism, and also the sexism, that exists in the courts of law. Three white men, two lawyers, prosecution and defence, and the judge, sit in a separate room during breaks. The judge, positioned from above, seems absorbed in his thoughts. Meanwhile, the two lawyers, who represent opposing parties, examine sexy photographs of Sueli (Wilma Dias) and talk about the physical attributes of the character, who committed suicide at the beginning of the movie. Sueli was in a romantic relationship with Fernanda (Monique Lafond), who now stands accused of murder. The photos are shown in court, followed by a strongly religious and vexatious speech.

Fernanda stands accused even though everyone knows she is not responsible for the death of Sueli. The defense attorney voices his astonishment that such a beautiful woman could commit suicide and the prosecuting attorney does not seem to disagree. Both engage in conversation like two good friends sharing a cigarette break. As the movie unfolds, the theatrical nature of the trial becomes clear. Three white men decide the future of Fernanda and, knowing her innocence, expose and humiliate her. However, Amor Maldito assumes a different premise, when compared to movies produced by black women today, where an afro-centric feminine gaze imposes itself. The emergence of black narratives in all fields of culture in Brazil and Portugal (but also around the world) is part of a struggle for greater female black protagonism in Brazil. According to Janaína Oliveira:

One of the research hypotheses I have developed in recent years on the participation of women in African and Afro-diaspora cinema, connects this presence with the educational dimension. In other words, what we see is that black women generally arrive after white women and after some form of access to direct or indirect training (Oliveira, 2018: 23).

In the Brazilian context, we can also relate the growth of intersecting feminism and the production of black women to the progressive inclusion favoured by the quota system for black students in Brazilian universities, based on the pioneering model established by the State University of Rio de Janeiro (UERJ), since 2003.

In movies, whiteness is depicted using deceptive means, such as white makeup and other elements, as in the recent (and emblematic) short films Kbela (Yasmin Thainá, 2015) and Rainha (Sabrina Fidalgo, 2016). In both, whiteness is invasive and violent. 
For instance, in Rainha, the female lead is a black woman who is chased by a group of women for much of the movie. Most of the chasers have white skin and all of them wear white makeup on their faces. When the group finally manages to trap the lead actress, who does a costume and makeup, all of them run their hands over her face and hair, undoing her makeup and hairstyle.

In Rainha, the female lead seems to want to escape the whiteness that haunts her for most of the movie, in order to destroy her beauty and take away her power. In Kbela, the white is shown as body paint that needs to be removed and cleaned. To the sound of dissonant jazz music, the movie opens with a depiction of racism, trauma, silencing, and an attempt to adjust and straighten the hair. The moments that follow the removal of the white paint symbolize the possibility of rebirth, through a process of capillary transition and communion with other black women, who at the end of the film sing: "to kill prejudice, I was reborn".

While Adélia Sampaio can be seen as part of the New Cinema movement, this new generation of black filmmakers wants to introduce an imagetic world centred on the representativeness of the black population as a determining and founding element of Brazilian identity and culture. In the words of Yasmin Thainá: "if the New Cinema created a new notion and new images of Brazil, I believe that black filmmakers need to create a new image of what it means to be black in Brazil" (TV Preta, 2018).

It seems clear that while in the New Cinema "what mattered was to build an agenda that would portray the Brazilian reality and the Brazilian people without actually engaging in a debate about racism in hegemonic representations" (Oliveira, 2016: 1), the present moment tries to find an imagetic creation process by black women, one that refers directly to an affirmation of blackness, questioning and portraying the advances of a coloniality of white power that invades spaces, as well as intra and extra-filmic gazes.

Movies like Kbela e Rainha impose a kinesthetic oppositional gaze to whiteness, articulating a sensory opposition that involves images, music, sounds, touch and movements. Of course, any film production can, to a greater or lesser extent, present and enhance the importance of other senses. However, in these two movies, the construction of the other as non-human or less than human is tackled through a combative multi-sensoriality.

These productions show how the oppositional gaze that was present in previous movies, which are here under analysis, starts from an ontological difference (Fejzula, 2019) imposed by structural racism and a coloniality of power. The films offer a sensorial and imagetic proposal that also questions the concept of national, sometimes reworking the very representations of nationality. 
The movie Rainha, for instance, presents a Carnival that is based on black and white, suffering and violence, contrasting with its more conventional representations. By the end, the lead actress appears to be hitchhiking in a truck to the sound of "Lei No, Lei Sta Ballando", a song about the Carnival sung by Chico Buarque in Italian. It is interesting to note that even the song that closes the film is not sung in Portuguese.

It is from an ontological difference imposed by whiteness and marked by institutional racism and a coloniality of power that the oppositional gaze offers an answer to the violent white gaze. By further investigating this ontological difference in the gaze, we see that the white gaze can be thought of as oculocentric (Pink, 2015), as its centrality is imposed by a Eurocentric project. Sight can be considered a privileged sense to understand and know the world. The white gaze labels, judges and places itself in the centre so as not to be positioned or named.

As hooks (1992) puts it, the control of the gaze with roots in the colonial period, starts to be questioned by an oppositional gaze that challenges and faces whiteness. Film production and the oppositional gaze viewed from a perspective of intersectionality and coloniality of power reveal how the nation-state and its institutions, cinema and stereotypes built by the media, traumatically affect black women. This analysis also reveals how these relationships of power can be questioned and confronted from a moviemaking point of view, which also brings to light the fight against racism and patriarchy.

\section{Acknowledgment}

Bruno Muniz wrote this article in the scope of the research project POLITICS - The politics of anti-racism in Europe and Latin America: knowledge production, political decision-making and collective struggles. This project has received funding from the European Research Council (ERC) under the European Union's Horizon 2020 research and innovation programme (grant agreement No ERC-2016-COG-725402).

\section{References}

Amparo Alves, J. (2018). The Anti-Black City: Police Terror and Black Urban Life in Brazil. Minneapolis: University of Minesota Press.

Andrade, C. \& Sales, M. (2020). Cinemas pós-coloniais e decoloniais em contextos de crise. In: XXII Encontro SOCINE, Goiânia. Anais de Textos Completos do XXII Encontro SOCINE. São Paulo: Socine - Sociedade Brasileira de Cinema e Audiovisual

Araújo, J. Z. (2016). Depoimento de Joel Zito Araújo sobre Zózimo Bulbul. Revista Raça. Retrieved from http://revistaraca.com.br/depoimento-de-joel-zito-araujo-sobre-zozimobulbul/ 
Araújo, J. Z. (2001). A negação do Brasil: o negro na telenovela brasileira. São Paulo: Editora Senac.

Araújo, J. Z. (2019). Cineasta e roteirista Joel Zito Araújo fala na ABL sobre o 'negro no cinema brasileiro. Academia Brasileira de Letras. Retrieved from: http://www.academia.org.br/noticias/cineasta-e-roteirista-joel-zito-araujo-fala-na-ablsobre-o-negro-no-cinema-brasileiro

Araújo, M. \& Maeso, S. (2016). Os contornos do eurocentrismo raça, história e textos políticos. Coimbra: Almedina.

Bulbul, Z. (Director). (1973). Alma no Olho [Film]. Brazil: Infinito Zodíaco.

Bulbul, Z. (Director). (1974). Artesanato do Samba [Film]. Brazil: Circofilm Produções de Arte.

Bulbul, Z. (Director). (1981). Dia de Alforria [Film]. Brazil: J. M. Produções e Embrafilme.

Bulbul, Z. (Director). (1988). Abolição [Film]. Brazil: Embrafilme.

Carvalho, N. \& Domingues, P. (2018). Dogma Feijoada. A invenção do cinema negro brasileiro. Revista Brasileira de Ciências Sociais, Vol. 33, № 96, 1-18.

Crenshaw, K. (1992). Whose Story Is It, Anyway? Feminist and Antiracist Appropriations of Anita Hill. In T. Morrison (ed.), Race-ing Justice, En-gendering Power (pp. 402-40). New York: Pantheon.

DiAngelo, R. (2011). White Fragility. International Journal of Critical Pedagogy, 3(3), 5470.

Fanon, F. (2002). The wretched of the earth. New York: Grove.

Farias, M. et al (Directors). (1962) Cinco Vezes Favela [Film]. Brazil: Centro Popular de Cultura.

Fejzula, S. (2019). The Anti-Roma Europe: Modern ways of disciplining the Roma body in urban spaces. Direito e Práxis, Vol. 10, № 3, 2097-2116. doi: https://doi.org/10.1590/2179-8966/2019/43882

Fidalgo, S. (Director). (2016). Rainha [Film]. Brazil: Synapse Produções.

GEMAA (2014). A cara do cinema nacional: gênero e cor dos atores, diretores e roteiristas dos filmes brasileiros (2002-2012). Retrieved from: http://gemaa.iesp.uerj.br/wpcontent/uploads/2014/10/images_publicacoes_TpD_TpD6_Gemaa.pdf

Hesse, B. (2004). Discourse on Institutional Racism: the genealogy of a concept. In D. Phillips, L. Turney, \& I. Law (eds.), Institutional Racism in Higher Education (pp. 131147). Stoke on Trent: Trentham Books.

hooks, b. (1992). Black Looks: Race and Representations. Boston: South and Press.

hooks, b. (2013). Representing Whiteness in the Black Imagination, in R. Frankenberg (ed.), Displacing Whiteness (pp. 165-179). Durham: Duke University Press. doi: https://doi.org/10.1215/9780822382270-006 
Mbembe, A. (2017). Critique of Black Reason. Durham: Duke University

Mediterranean Institute of Gender Studies (2009). Glossary of Gender-Related Terms. Retrieved from: http://www.intergroupresources.com/rc/Intersectionality\%20\%20a\%20Tool\%20for\%20Gender\%20\&\%20Economic\%20Justice.pdf

Negro, Q. (Director). (1979). Um Crioulo Brasileiro [Film]. Brazil: Alter Filmes.

Oliveira, J. (2016). Kbela e Cinzas: o cinema negro no feminino do "Dogma Feijoada" aos dias de hoje. In: AVANCA. Avanca Cinema International Conference, 2016: Edições Cine-Clube de Avanca. Vol. 1. p. 646-654.

Oliveira, J. (2017). Cinema negro contemporâneo e o protagonismo feminino. In: Freitas, K \& Almeida, P. R. G. de. Diretoras negras no cinema brasileiro. Rio de Janeiro: Caixa Cultural do Rio de Janeiro.

Onofre, W. (Director). (1975). As Aventuras Amorosas de um Padeiro [Film]. Brazil: Embrafilme.

Pink, S. (2015). Doing Sensory Ethnography. London: Sage. https://doi.org/10.4135/9781446249383.n2

Pitanga, A. (Director). (1978). Na Boca do Mundo [Film]. Brazil: Lente Filmes.

Quijano, A. (1998) Colonialidad del Poder, Cultura y Conocimiento en América Latina. Anuário Mariateguiano, Vol. 9, № 9, 113-122

Rocha, G. (Director). (1968). Terra em Transe [Film]. Brazil: Mapa Produções Cinematográficas.

Sales, M. (2018). Pós-colonialismo(s) e o cinema brasileiro. Buala. Retrieved from: https://www.buala.org/pt/afroscreen/pos-colonialismos-e-o-cinema-brasileiro-aretomada

Sales, M. (2019). Cinema negro português. In: Avanca Cinema International Conference, 2019. Avanca Cinema 2019. Avanca: Edições Cine-Clube de Avanca, 2019. Vol. 1. p. 325-329.

Sampaio, A. (Director). (1979). Denúncia Vazia [Film]. Brazil: A. F. Sampaio Produções Artísticas.

Sampaio, A. (Director). (1984) Amor maldito [Film]. Brazil: A. F. Sampaio Produções Artísticas.

Souza, E. P. (2020). Mulheres negras na construção de um cinema negro no feminino, Aniki, Vol.7, № 1

Squires, J. (2007). Diversity Mainstreaming: Moving Beyond Technocratic and Additive Approaches. Femina Politica, 1, 45-56.

TV Preta (2018). \#21 Yasmin Thayná: Afronta! (Face it!). Retrieved from: https://www.youtube.com/watch?v=p23D6EvY0o4

Yuval-Davis, N. (2006). Intersectionality and Feminist Politics, Vol. 13, № 3, 193-209. Retrieved from: https://doi.org/10.1177/1350506806065752ï 
Michelle Sales is Professor at the School of Fine Arts at the Federal University of Rio de Janeiro, Brazil. She has been a researcher of the Centre for Interdisciplinary Studies at the University of Coimbra, Portugal since 2008. She is currently coordinating the research projects: Outside Portuguese cinema: studies on contemporary Portuguese black cinema (Fundação Calouste Gulbenkian 2019-2020); The Contemporary Artistic Practices in the Ibero-American context: postcolonial studies and the decolonial turn (UFRJ 2020-2022).

凶sales.michelle@gmail.com

Bruno Muniz holds a PhD in Sociology at the London School of Economics and Political Science. $\mathrm{He}$ is currently a postdoctoral researcher at the Center for Social Studies (CES) of the University of Coimbra - Portugal.

凶bmuniz@gmail.com 